\title{
Utilization of Techno-Ecological Agricultural Models for Increasing the Carrying Capacity of Food Land in the Padang City
}

\author{
Rahmanelli $^{1 *}$, Ratna Wilis ${ }^{12}$, Sugeng Nugroho ${ }^{3}$, and Helfia Edial ${ }^{12}$ \\ IDepartment of Geography, Faculty of Social Sciences - State University of Padang, Indonesia \\ ${ }^{2}$ Doctoral Program of Environmental Sciences, Postgraduate - State University of Padang, Indonesia \\ ${ }^{3}$ Padang Pariaman Climatology Station, BMKG Sumatera Barat \\ *Corresponding author. Email: rahmanelli@fis.unp.ac.id
}

\begin{abstract}
Techno-ecological agriculture seeks to combine the strengths of ecological agriculture with technologically advanced agriculture, so that a more productive, efficient and quality agricultural model with less risk and environmentally friendly will be formed. Population growth will encourage people to open new agricultural lands, causing a decrease in the carrying capacity of agricultural land. The objectives of this study are (1) to analyze land use changes in the city of Padang in 2007 and 2019, (2) to analyze the benefits of the techno-ecological agricultural model in determining the capacity of land in the city of Padang, (3) to calculate the carrying capacity of land for food as a result of its application. Techno-ecological agricultural model in Padang City. This study uses an approach, namely a quantitative descriptive approach, with these variables concerning changes in land use, land capability and carrying capacity of agricultural land for food crops. The population in this study were all areas in the city of Padang consisting of 11 districts, while the sample was areas that were only planted with rice. The results of the study describe (1) The change in paddy fields occurred from 2007 covering an area of 7,266,815 hectares, while in 2019 it decreased to 5,263,489 hectares. (2) Land capability for class III covering an area of 1,399.85 ha, Class IV covering an area of 21,870.08 ha, Class VI covering an area of ?? 4,048.8, and class VII covering an area of 41,051.37 ha, (3) Carrying capacity of food land for rice fields in Padang City produces a value of 0.051 which is included in class III, which means that the city of Padang is an area that has not been able to do food self-sufficiency.
\end{abstract}

Keywords: Techno ecology, Land capability, carrying capacity

\section{INTRODUCTION}

The need for rice for the Indonesian people in 2030 is around 59 tons of rice. Meanwhile, in 2008, we were only able to produce about 40 million tons of rice. To meet the demand for rice, of course, requires extra hard efforts considering that the conversion of agricultural land, especially rice fields to non-agricultural land, is still happening, so that it will increase the difficulty in achieving the fulfillment of rice needs.

In the midst of the risks that are not easy for farmers to face, the phenomenon of climate change has emerged, which has a significant impact on farmers, especially rice farmers. Global climate change causes a long dry season or excessive rainy season with high rainfall intensity [1]. An increase in air temperature will also have an impact on decreasing crop productivity, especially in seasonal crops. This condition also affects livestock productivity. Besides that, an increase in air temperature will also increase the attack of pests and diseases, both in plants and livestock stars [2]

Several related studies explain the conversion of forest and agricultural land to residential land, so that it will directly cause an extreme temperature index trend that occurs in Padang City [3]. Some extreme climate indices (surface air temperature and rainfall) in Tanah Datar Regency which are used to detect the presence of climate change show signs of this change [4]. Climate change is also thought to have caused the occurrence of extreme climates that increased in rain posts in the Batang Kuranji and Batang Air Cold Batang, particularly a trend that depicts a decrease in the amount of rain such as a decreasing trend in the amount of rainfall [5]. 
The techno-ecological agricultural model seeks to combine the strengths of ecological agriculture with technologically advanced agriculture, so that a more productive, efficient and quality agricultural model with less risk and environmentally friendly will be formed. Even techno-ecological agriculture that combines a cycle production system (circulation of nutrients and biomass in one chain) with a touch of advanced technology, can lead to "zero waste" or agriculture without waste. Ensure the right variety of varieties that are low in greenhouse gas emissions (GHG), is resistant to inundation or drought, is resistant to certain pests and diseases, and has high productivity [1]. Techno-ecological agriculture is expected to improve the welfare of farmers so that they can survive comfortably as rice producers [6].

Indonesia needs a large of increase in rice production in the future to keep up with the rapid population growth. Increasing agricultural production can be done by providing inputs to agricultural locations, including mapping land resources and evaluating land suitability in each land mapping unit. With the GIS application, the input data can be quickly applied to a map of agricultural land use [7]. Population growth will encourage people to open new agricultural lands, causing a decrease in the carrying capacity of agricultural land [8]. From the description above, it is clear how important it is to respond to climate change by applying a technoecological agricultural model so that the carrying capacity of food agriculture can be increased.

\section{RESEARCH METHOD}

This study uses an approach, namely a quantitative descriptive approach, with these variables concerning changes in land use, the carrying capacity of agricultural land for food crops, and land capability. The sample in this study is all areas in the city of Padang, there were 1 district, while the sample was areas that only planted with rice.

Data

Data used to measure changes in paddy fields, land suitability, while primary data is used to measure the carrying capacity of agricultural land. Changes in land use are needed to see changes in paddy fields from 2007 to 2019. The data used are Landsat-5 TM 2007 and Landsat-8 OLI 2019 imagery. Detail information of human population and productivity agriculture area obtained from BPS. To calculate the carrying capacity of the land carrying capacity in the agricultural sector, it is obtained from a comparison between the available land and the number of farmers. The indicators are: Harvested Area, Population, Minimum Physical Needs, and Average Land Production. As for land capability, the capability map is obtained from the overlay of slope maps and soil characteristics maps. The method used in the land capability analysis is the matching method.

\section{Data processing \\ 1. Land Cover Change}

To identification agricultural changes we use spatial analysis, which to obtain the information about the land cover can also by interpreting the Imagery [9]. Where image analysis process used multi spectral satellite image classification, this techniques used algorithm Maximum Likelihood as part of supervised classification, which is known as a well-established image classification statistical model in grouping pixels for land cover identification [10]. It possible to compute the statistical probability of a pixel vector being a member of each spectral class [11]. The land cover map tested was processed in a standard manner, both in terms of sample selection and implementation of classification [12]. The output from interpretation Landsat-5 TM 2007 and Landsat-8 OLI 2019 imagery is land cover maps, both of map will overlay to calculate the large of area changes.

\section{Land Capability for Development Paddy Field}

To perform this analysis, a land capability map is required. The capability map is obtained from the overlay of the slope map and the soil characteristic map, with the parameters listed in table 4 . The method used in the land capability analysis is the matching method with land potential factors by considering the highest resistance as a determinant of land capability class [13]. 
Table 1. Parameter of Land Capability

\begin{tabular}{lcccccccc}
\hline \multirow{2}{*}{ Limiting Factor } & \multicolumn{8}{c}{ Class of Land Capability } \\
\cline { 2 - 9 } & I & II & III & IV & V & VI & VII & VIII \\
\hline 1. Soil Texture on Layer (40cm) & $\mathrm{t} 2 / \mathrm{t} 3$ & $11 / \mathrm{t} 4$ & $11 / \mathrm{t} 4$ & $\mathrm{~T} 1 / \mathrm{t} 4$ & $11 / \mathrm{t} 4$ & $11 / \mathrm{t} 4$ & $11 / \mathrm{t} 4$ & $\mathrm{t} 5$ \\
2. Soil Texture Under Layer & $\mathrm{t} 2 / \mathrm{t} 3$ & $\mathrm{t} 1 / \mathrm{t} 4$ & $11 / \mathrm{t} 4$ & $\mathrm{~T} 1 / \mathrm{t} 4$ & $11 / \mathrm{t} 4$ & $11 / \mathrm{t} 4$ & $11 / \mathrm{t} 4$ & $\mathrm{t} 5$ \\
3. Slope (\%) & 10 & 11 & 12 & $\mathrm{~L} 3$ & 13 & 14 & 15 & 16 \\
4. Drainage & $\mathrm{d} 0 / \mathrm{d} 1$ & $\mathrm{~d} 2$ & $\mathrm{~d} 3$ & $\mathrm{D} 4$ & $\mathrm{~d} 5$ & $\mathrm{~d} 4$ & $\mathrm{~d} 4$ & $\mathrm{~d} 4$ \\
5. Depth of Solum & $\mathrm{k} 0$ & $\mathrm{k} 0$ & $\mathrm{k} 1$ & $\mathrm{~K} 2$ & $\mathrm{k} 2$ & $\mathrm{k} 3$ & $\mathrm{k} 3$ & $\mathrm{k} 3$ \\
6. Soil Erosion & $\mathrm{e} 0$ & $\mathrm{e} 1$ & $\mathrm{e} 1$ & $\mathrm{E} 2$ & $\mathrm{e} 2$ & $\mathrm{e} 3$ & $\mathrm{e} 4$ & $\mathrm{e} 4$ \\
7. Open Rock & $\mathrm{b} 0$ & $\mathrm{~b} 0$ & $\mathrm{~b} 0$ & $\mathrm{~B} 1$ & $\mathrm{~b} 2$ & $\mathrm{~b} 2$ & $\mathrm{~b} 2$ & $\mathrm{~b} 3$ \\
8. Flood Risk & 00 & 01 & 02 & 03 & 03 & 03 & 03 & 03 \\
\hline
\end{tabular}

3. Carrying Capacity of Land for Developing Paddy

For analysis carrying capacity of the land for developing paddy area in Padang City, which used equation [8]:

$$
\tau=\frac{\mathrm{Lp} / \mathrm{Pd}}{\mathrm{KFM} / \mathrm{Pr}}
$$

Where:

$$
\begin{array}{ll}
\mathrm{T} & =\text { Carrying capacity for paddy development } \\
\mathrm{Lp} & =\text { Large of paddy area }(\mathrm{Ha}) \\
\mathrm{Pd} & =\text { Population } \\
\mathrm{KFM} & =\text { Minimum of physic necessary } \\
\mathrm{Pr} & =\text { average of land production per hectare } \\
& \mathrm{Kg} / \mathrm{Ha})
\end{array}
$$

Based on these analysis the classification determined is: Class I $\sigma>1$ An area capable of self-sufficiency in food and capable of providing a decent life for the population.

Class II $\sigma=1$ The area has an optimal environmental carrying capacity. So number 1 is the environmental carrying capacity threshold

Class III $\sigma<1$ Areas that are not yet able to be selfsufficient in food.

\section{RESULT OF THIS RESEARCH}

\subsection{Geographical on Padang City}

Padang City is the capital city of West Sumatra Province, which is located on the west coast of Sumatra Island and has an astronomical position between $100^{\circ}$ 05 '05' 'BT - 100³4'09' 'BT and 0044'00' 'LS $01^{\circ} 08^{\prime} 35^{\prime}$ LS. Padang City physically has different characteristics from other cities in West Sumatra Province. There are 3 (three) characteristics that stand out:

a. Coastal Areas, namely the entire coastal area facing the Indian Ocean.

b. Lowland areas, namely areas that are mostly developed and part of the downtown area

c. The highland area, which is the area on the slopes of the Bukit Barisan that circles the city of Padang.

In 1980 the area of Padang City, which previously consisted of 3 Sub-Districts with 15 Villages, was developed into 11 Districts and 193 Sub-Districts, then with the enactment of Regional Regulation Number 10 of 2005, a merger was carried out into 104 sub-districts. The largest sub-district area is Koto Tangah Subdistrict, namely $232.25 \mathrm{Km} 2$ or $33.42 \%$, while the smallest sub-district area is Padang Barat Subdistrict, namely $7 \mathrm{Km} 2$ or $1.01 \%$, as shown in Table 3.1.

\subsection{Topographical on Padang City}

The area of Padang City has a varied topography, a mixture of sloping land and steep wavy hills. Most of the topography of the city of Padang has an average land coverage level of $40 \%$. Topographical conditions of the city of Padang can be seen from two aspects. the slope of the land

1) Areas with a land slope of $0-2 \%$ are in West Padang, East Padang, North Padang, Nanggalo, parts of Kuranji, South Padang, Lubuk Begalung and Koto Tangah Districts.

2) Areas with a land slope of between $2-15 \%$ are scattered in Koto Tangah District, Pauh District and Lubuk Kilangan District, which are in the middle of Padang City.

3) Areas with $15-40 \%$ slope of land are scattered in Lubuk Begalung, Lubuk Kilangan, Kuranji, Pauh and Koto Tangah Districts.

4) Areas with more than $40 \%$ slope of land are scattered 
in the eastern part of Koto Tangah, Kuranji, Pauh Subdistricts and the southern part of Lubuk Kilangan Subdistricts and Lubuk Begalung Districts and most of Bungus Teluk Kabung Districts. This area is an area that has been designated as a protected forest area.

\subsection{Land Use Changes from 2007 to 2019}

The analysis that will be carried out is to see the changes in land use in the city of Padang in 2007 and 2019. Result of this analysis of the two images, a comparison of land use changes.

Overall, there have been significant changes in several types of land cover. This change is more dominant in natural land cover types such as forest, it changes to land cover which is influenced by human activities. This change is not only a reduction in the type of land cover, but also an increase in land use area in several categories. To begins with identifying and supervised classification to extract land cover information form Landsat-5 TM 2007 and Landsat-8 OLI 2019. The results of classified into types of land use in 2007 which where consisting of types of land use Primary Forest 36,891,656 Ha, Secondary Forest 10,437,473 Ha, settlement 8,146,363 Ha, Bush / Scrub 4,349,169. In 2019 the primary forest covering an area of 29,624,197 Ha, Secondary Forest $10,437,473$ hectares, housing area of $8,153,473$ hectares, irrigated rice fields 5,263,489 hectares, moor / fields $7,180,702$ hectares, and shrubs of 4,353,582 hectares which dominate land use in 2019.

Figure 1. Diagram Land Use Change from 2007 to 2019

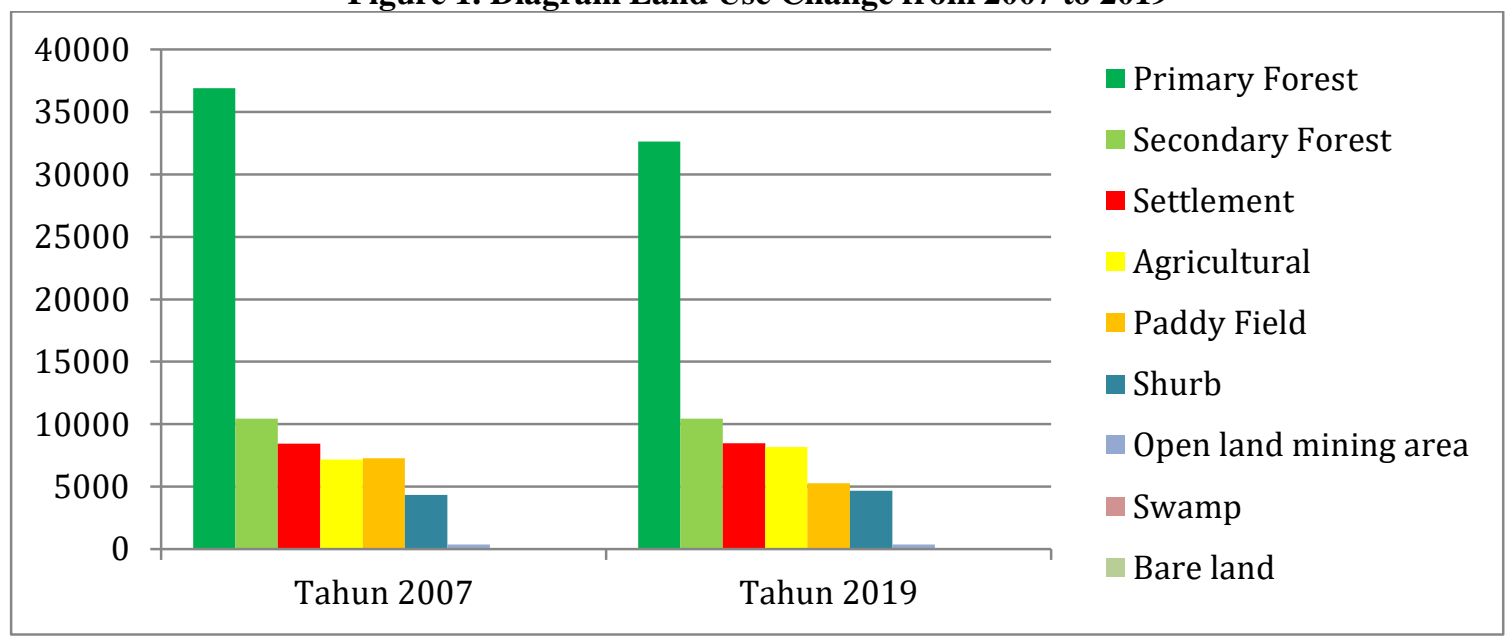

Overall, the diagram above reveals how the land cover change illustrates. From the chart above, it can also be seen that the land use in 2007 the open land mining areas is $361,510 \mathrm{Ha}$, Rice fields 7,266,815 $\mathrm{Ha}$, bare land 55,049 $\mathrm{Ha}$, and Graves / Cemeteries 2,043 Ha. However in 2019 it can be seen that land use for Open land mining area 361,510 Ha. Bare land 14,325 Ha, For more details regarding land use in 2019.
The distribution of land use changes in the city of Padang will be more clearly seen in the comparison map of land use in 2007 and 2019. This spatial distribution also informs how the development of agricultural land, where in some locations there is also a reduction and increase in area. 


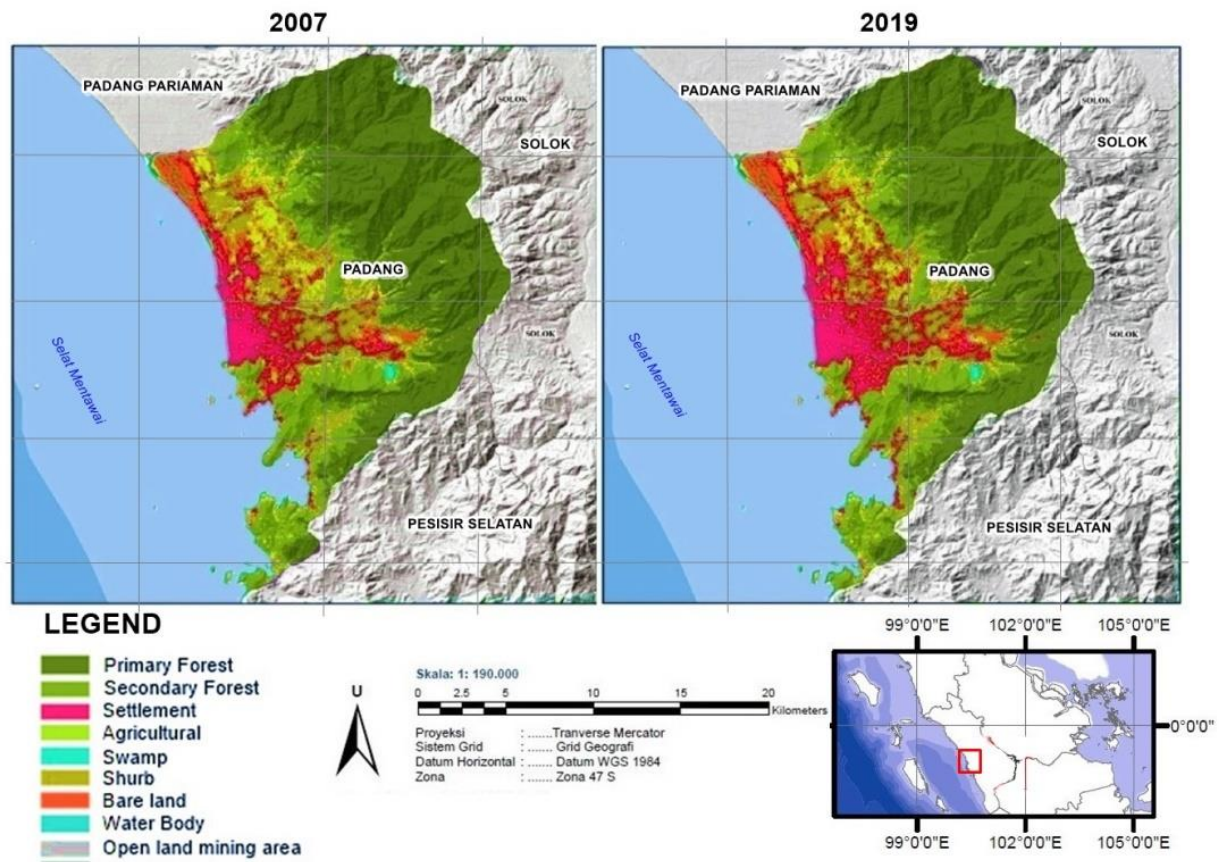

Fugure 2. Land Use Changes on Padang City

\subsection{Land Capability}

Evaluation of land capability is an effort to utilize land according to its potential. Assessment of land potential is indispensable in order to formulate policies, use and manage land in a sustainable manner. To formulate this policy, maps are needed, one of which is a map of land capability. In the land capability map, the land capability class is presented for land that can be cultivated for agricultural purposes. The land capability map for the city of Padang can be seen in Figure 3 below.

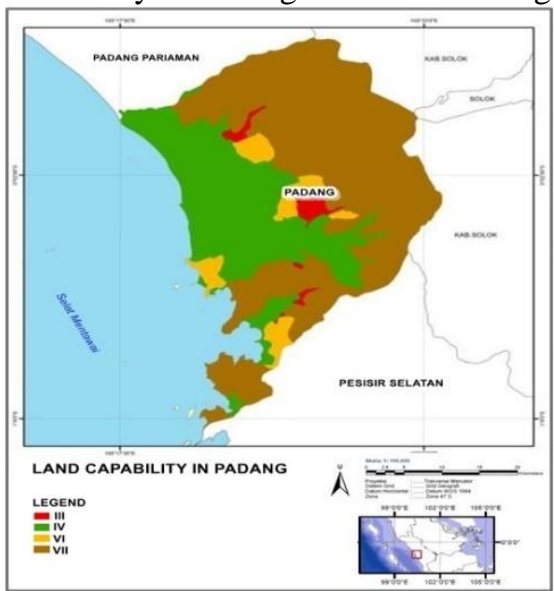

The results of the land capability analysis produce a map of the land capability of the Padang city. The results of the analysis show that there are 4 land capability classes consisting of land capability class III, land capability class IV, land capability Class VI and land capability class VII. The land capability of Padang City is dominated by the land capability of class VII which is in the eastern part. The following table shows the area of each class of land capability in the city of Padang.

Table.2. Land capability

\begin{tabular}{llll}
\hline No & Class & Large $(\mathbf{H a})$ & $\mathbf{( \% )}$ \\
\hline 1 & III & 1399.85 & 2.05 \\
2 & IV & 21870.08 & 32 \\
3 & VI & 4048.8 & 5.92 \\
4 & VII & 41051.37 & 60 \\
Total & & $69495 . t$ & 100 \\
\hline
\end{tabular}

The land capability of Padang City is dominated by the land capability of class VII with an area of $60 \%$. Class VII land capability has a slope limiting factor with a slope of more than $45 \%$ and is classified as heavy erosion. This limiting factor is a formidable obstacle and cannot be removed. Class VII land is not suitable for agricultural cultivation. If it is used for pasture or production forest, it must be done with heavy erosion prevention efforts. Furthermore, the class IV is at number 
of $32 \%$. This class has a limited selection of plants. Soils in class IV can be used for seasonal crops and agricultural crops and in general, grass plants, production forests, pastures, protected forests and nature reserves. Furthermore, the land capacity of class VI is dominated by $6 \%$ area. It have slope limiting factor with a slope of $25-45 \%$, heavily eroded, very shallow depth of shallow roots. Its use is limited to grass or pasture, production forest, protection forest, or nature reserves. The last is the land capacity of class III with an area of only $2 \%$.

Class III land can be used for seasonal crops and plants that require tillage, grass plants, grasslands, production forests, protected forests and animal reserves. Land in class I to class IV with good management is able to produce and is suitable for various uses such as for agricultural cultivation in general (seasonal and annual crops), grass for fodder, pasture and forest. Land in class $\mathrm{V}$, VI, and VII is suitable for plants and or natural vegetation. In some cases, classes V and VI can be used for certain crops such as fruits, ornamental plants or flowers and even high value vegetables with proper management and conservation measures [14]. The people need for crop diversification for higher production. The variety of commodities being maintained causes an increase in the nutrient cycle of the land. The type and distribution of land use has a significant effect on water demand [15]. Farmers' level of understanding of the climate and adaptation options that will be made can be increased by involving them in different organizations such as climate field schools and farmer associations. This is important to adapt to climate change and increase agricultural productivity [16].

\subsection{Carrying Capacity of Agricultural Land}

Population pressure is a serious problem in the carrying capacity of agricultural land, because with population pressure it will encourage farming communities to increase their work. The increase in population will reduce the carrying capacity of the land and will increase the damage to the existing land. The carrying capacity of the land in Padang City is as follows: Table 3. Carrying Capacity

\begin{tabular}{lll}
\hline No & Type & Total \\
\hline 1 & Human Population & 927.168 \\
2 & Large Area & $5.263 \mathrm{Ha}$ \\
3 & $\begin{array}{l}\text { Number of minimum phisic } \\
\text { necessary }\end{array}$ & $2.100 \mathrm{calori} /$ day \\
& $\begin{array}{l}\text { Average of agricultural } \\
\text { production }\end{array}$ & $15.429 \mathrm{Kg} / \mathrm{Ha}$ \\
& & \\
\hline
\end{tabular}

$$
\tau=\frac{5263: 927.168}{2.100: 15.429}=0.0417
$$

\section{CONCLUSION}

From the calculations made, it was found that the carrying capacity of the rice agricultural food area was 0.051. The carrying capacity is included in Class III, meaning that the City of Padang is not yet able to carry out food self-sufficiency. Population pressure is inversely proportional to carrying capacity. The higher the population pressure, the lower the carrying capacity. The increase in permukinan occurs as the population increases rapidly [3]. The high rate of conversion of paddy fields poses a threat to the food security of the population. Food security can be achieved if the available food can meet the food needs of the entire population [18],[19]. Population pressure is a serious problem in the carrying capacity of agricultural land, because the pressure from the population to eat will encourage the farming community to increase their work [8].

\section{ACKNOWLEDGMENT}

The authors wish to thank Government of Padang City for support and we also express our gratitude to all those who have helped with the administration process, as well as those who helped us in the field. Nevertheless, thanks for research team help this research become to success and share in knowledge sharing platform.

\section{REFERENCES}

[1] Wilis, R. 2017. Geografi Pertanian. Sukabina Press. ISBN :978-602-6277-62-6 Padang.

[2] Guntoro, Suprio. 2011. Saatnya Menerapkan Pertanian Tekno-ekologis. PT Agromedia Pustaka. Jakarta egasains, Volume 34.

[3] Hermon, Dedi dan Wilis, Ratna (2017). Deteksi dan Adaptasi Perubahan Iklim di Kota Padang. Laporan Peneltian Hibah Bersaing tahun 2013.

[4] Wilis, R. 2016. Perubahan Iklim dan Dampaknya terhadap Produktifitaas Tanaman Padi di kabupaten Tanah Datar. Jurnal Geografi Vol. 5 No. 1. ISSN 2086-7042. 40-51.

[5] Nugroho, Sugeng, Ratna W. The Decreasing Trend of Precipitation Observed at Watersheds in Indonesia. IOP Conf. Series: Earth and Environmental Science 145 (2018) 012099 doi :10.1088/1755-1315/145/1/012099.

[6] Rahmanelli, R Wilis, dan Afdhal. 2020. Responding to Climate Change by Applying the TechnoEcological Agriculture Model. Advances in Social Science, Education and Humanities Research, 
volume 464. Proceedings of the 1st Progress in Social Science, Humanities and Education Research Symposium (PSSHERS 2019).

[7] Wilis, Ratna, E. Barlian, D. Hermon, I, Dewata, Iswandi, U. 2020. Evaluation of Carrying Capacity Lands for Food Agriculture Based on Land Degradation in Pagar Alam City - Indonesia. International Journal of Management and Humanities (IJMH) ISSN: 2394-0913, Volume-4 Issue-9, May 2020.

[8] Muta`Ali, L. 2012. Daya Dukung Lingkungan untuk Perencanaan Pengembangan Wilayah. Badan Penerbit Fakultas Geografi (BPFG). Yokyakarta.

[9] Hidayat R A and Hanif M. 2020. Spatial Modeling of The Threat of Damage to The Peatland Ecosystem In The Mainland of Bengkalis Regency, Riau Province. Journal Social Polites. Vol 20. Special Issue. No 2. doi: 10.33541/sp.v21i3.2249.

[10] Hanif M, et.al. 2019. Multi Spectral Satellite Data to Investigate Land Expansion and Related to Micro Climate Change as Threat to The Environment. Journal IOP Conf. Series: Earth and Environmental Science. Volume. 303. doi: 10.1088/17551315/303/1/012030.

[11] Weng Q. 2011 Advances in Environmental Remote Sensing, Sensor, Algotihma and Applications. Indiana State Univeristy. ISBN: 978-1-4200-91816.

[12] Hanif, et.al. 2017. Investigation Character of Natural Forest Ecosystem, Use High Resolution and LiDAR Data. Journal of Environment and earth Science (IISTE). 2224-3216 (paper) 2225-0948 (Online). Volume 7, Nomor 10, hal 138-145.

[13] Arsyad, Sitanala, dan Rustiadi Ernan. 2012. Penyelamatan Tanah, Air, Dan Lingkungan. Yayasan Pustaka Obor Indonesia. Bogor.

[14] Sartohadi J, Jamulya, Nur ISD. Pengantar Geografi Tanah. Pustaka Pelajar. 2012.

[15] Gandolfi, C. et al. (2014) 'Integrated modelling for agricultural policies and water resources planning coordination', Biosystems Engineering. Elsevier Ltd, 128, pp. 100-112. doi: 10.1016/j.biosystemseng. 2014.06.006.

[16] Hasan, M. K. and Kumar, L. (2019) 'Comparison between meteorological data and farmer perceptions of climate change and vulnerability in relation to adaptation', Journal of Environmental Management. Elsevier, 237(August 2018), pp. 5462. doi: 10.1016/j.jenvman.2019.02.028.

[17] Hermon, Dedi and Iskarni, Paus and Oktorie, Olivia and Wilis, Ratna (2017). The Model of Land
Cover Change into Settlement Area and Tin Mining and its Affecting Factors in Belitung Island, Indonesia. Journal of Environment and Earth Sciende, 7 (6). pp. 32-39. ISSN 2224-3216 (Print) 2225-0948 (online)

[18] Sunanto, \& Rauf, A. W. (2018). Respon Petani Terhadap Pelaksanaan Displai Padi Gogo VUB Pada Lahan Sub Optimal. Jurnal Sosial Ekonomi Pertanian, 14(2), 143- 160.

[19] Wilis, Ratna, E. Juita, I, Suryani. Farmers Group Development Potential Through The Make Straw Compost In Nagari Lima Kaum Tanah Datar Regency West Sumatra. Science and Environmental Journals for Postgraduate Vol. 2 No. 2 (pp. 7-13) June 2020 p_ISSN 2655-5085 e_ISSN 2655-5239. 